\title{
Computational Thinking Goes to School: Implications for Teacher Education in Brazil
}

\author{
Taciana Pontual Falcão \\ Universidade Federal Rural de Pernambuco - UFRPE \\ Departamento de Computação \\ taciana.pontual@ufrpe.br
}

\author{
Rozelma Soares de França \\ Universidade Federal Rural de Pernambuco - UFRPE \\ Departamento de Educação \\ rozelma.franca@ufrpe.br
}

\begin{abstract}
Integrating Computational Thinking (CT) and Computer Science (CS) concepts into school curricula is a global trend nowadays. However, most research and educational programs and products focus on students' needs, while much less work is being done on teacher education, so that they develop subject and pedagogical knowledge on CT. Reflecting an encouragement for autonomous learning, some CT resources for in-service teachers are available, such as online courses for building capacity as well as tools and activities for lessons. Meanwhile, the Brazilian government has already determined that CT must be present in school curricula and also in teacher education programs from all areas of knowledge. Nevertheless, little change is perceived in Brazilian schools, and knowledge about CT among school teachers is still incipient, indicating that, for teachers to integrate CT within their disciplines, in service development might not be sufficient. Meanwhile, faculty from teacher education programs have been mostly unresponsive to the new demands related to CT, and face the not surprising barrier of their own lack of knowledge on the topic. In the Brazilian context, CS teacher education programs could be a key to solving this puzzle, as both faculty and student teachers are dealing with CS Education and CT. However, CS student teachers remain isolated and often ignored by national policies, while most investment is made on in-service development for school teachers. This paper presents CT research in Brazil related to teacher education, resources for in-service training, the potential contribution of the CS teacher education programs, and, within this context, discusses which directions could be followed to inform national policies and curricula adaptations in higher education institutions (HEI). More attention must be given to developing CT in HEI, including faculty's CT knowledge and curriculum redesign. In this direction, the new Brazilian network of CS teacher education programs (ReLic) has a great potential to establish an interdisciplinary dialogue that could help meet the demands of contemporary education.
\end{abstract}

Keywords: Computational thinking; Computer science teacher education; Curriculum; Higher education.

\section{Introduction}

Since its publication in 2006, Jeannette Wing's vision of Computational Thinking (CT) as a necessary skill for all (Wing, 2016) has spread at a quick pace. Not only did it become a very popular term, but it also revived the idea of introducing Computer Science (CS) concepts in schools proposed decades earlier by Seymour Papert and Cynthia Solomon (1972). As a result, CS concepts are now officially integrated into school syllabi in several countries (Vicari, Moreira, $\&$ Menezes, 2018). However, this global educational trend faces the great challenge of teacher education. Although it is obvious that deciding that children must learn a specific content entails that someone must teach them, these two sides of the same coin are not getting the same amount of attention from policymakers and governmental institutions. Moreover, down the path re-opened by Wing's position paper, there is a blurred and often misunderstood distinction between: (i) integrating CT to the teaching of all contents; and (ii) teaching CS concepts. While the latter clearly demands dedicated CS teachers in schools, for the former the expectation is put on teachers from all disciplines, who must learn about CT and be able to apply it in the teaching of their

Cite as: Pontual Falcão, T., \& França, R. S. (2021). Computational Thinking Goes to School: Implications for Teacher Education in Brazil. Revista Brasileira de Informática na Educação, 29, 1158-1177. DOI: 10.5753/rbie.2021.2121 
particular subject, thus making children develop CT in a contextualized manner. This is by no means an easy or quick process (Barr \& Stephenson, 2011).

This CT/CS trend officially reached Brazilian education in 2018, when the term "computational thinking" appeared in the National Learning Standards for schools (Base Nacional Comum Curricular - BNCC) (MEC, 2018), as a cross-cutting theme (though particularly related to mathematics), and with the following definition: "CT involves the skills of understanding, analyzing, defining, modeling, solving, comparing and automating problems and their solutions, in a methodical and systematic manner, by developing algorithms" (MEC, 2018, p. 474) (our translation). In the same year, and drawing from BNCC, the non-profit association Center of Innovation for Brazilian Education (Centro de Inovação para a Educação Brasileira - CIEB) proposed a Curriculum in Technology and Computing for pre-school and primary education (CIEB, 2018) with three axes: digital culture, digital technology and computational thinking. CT is defined in this curriculum as: "the skill to solve problems from knowledge and practices of computing, including systematizing, representing, analyzing, and solving problems. [...] it is also applied to describe, explain and model the universe and its complex processes" (CIEB, 2018) (our translation). This curriculum proposes activities in each axis connected with abilities from BNCC, along with the level of "technology adoption" demanded of schools and teachers to be able to develop them (from basic to advanced). However, there is no guidance for teachers on how they could reach each level, so as to be able to conduct the proposed activities.

Throughout the BNCC conception, the Brazilian Computer Society (Sociedade Brasileira de Computação - SBC) took part in public auditions held by CNE, presenting competencies, abilities and CS contents to be added to the proposal, and also making suggestions of amendments. SBC's participation started with a working group created in 2016, under its educational board. However, given the complexity of the theme, its peculiar needs which very much differed from those of the educational board (so far focused on higher education), and the amount of necessary actions, in 2018 the working group evolved to the creation within SBC of an independent board specifically dedicated to school education ${ }^{1}$, showing a strong political will to have a voice in the process. However, SBC's position in favour of the integration of CS concepts in school curricula was not met in the BNCC, which led to the publication, in 2018, of a technical note reinforcing the importance of the inclusion of CS in schools and stating that SBC's suggestions for the BNCC had not been considered (SBC, 2018).

In 2019, SBC officially presented, in the institutional website, guidelines for primary and secondary education that recommend the teaching of CS concepts in schools at compatible depth with each educational level (SBC, 2019a). In this document, CT is defined as "the ability to understand, define, model, compare, solve, automate and analyze problems (and solutions) in a methodical and systematic manner" (SBC, 2019a, p. 2) (our translation). The document is contentfocused and assumes that teachers have the skills to deploy the curricula. In the same year, CT was included in the Ministry of Education national guidelines for teacher education degrees in all areas of knowledge (MEC/CNE, 2019). According to this document, all student teachers must develop a "basic comprehension of digital phenomena and computational thinking, as well as their implication in contemporary teaching-learning processes" (p. 6, our translation). However, so far this has not had any effect in teacher education undergraduate programs in Brazil (licenciaturas) (except for CS teacher education programs). In fact, these programs have been mostly unresponsive to the integration of technologies in teaching and learning processes in the first place - which has been advocated in the country (and worldwide) for more than 40 years. The curriculum of most Brazilian teacher education programs has none to one mandatory course on technologies in education.

${ }^{1}$ https://www.sbc.org.br/educacao/diretoria-de-educacao-basica 
In 2020, CIEB released the version of their curriculum for secondary education (CIEB, 2020), keeping the same axes of knowledge (digital culture, digital technology and computational thinking). For each competency in this curriculum, several activities are suggested, along with a "teacher profile" which informs the level of "knowledge in informatics" needed (from basic to advanced).

In April 2021, after a few years of close collaboration with SBC, the National Education Council (Conselho Nacional de Educação - CNE) made publicly available an official proposal for the integration of CS concepts in Brazilian schools (MEC/CNE, 2021), open to suggestions from any citizen or organization. This event was celebrated by SBC and the educational and research communities that support the introduction of computing in schools because, although political and bureaucratic phases are still to come, if the CNE proposal is approved by the government, eventually all schools will have to adapt their curriculum to include the CS concepts recommended in the document.

In this context, the CS teacher education programs (in Brazil mostly known as Licenciatura em Computação and existing since 1997), often regarded as the "ugly duckling" in teacher education, might as well become a "sleeping beauty" (Lemos, 2013). So far, the lack of an official teaching position in schools often drives CS teachers to extracurricular activities like robotics competitions and programming clubs, or to being the informatics lab technician (typically with lesser pay in both cases than the "actual" school teachers). With the envisioned formalization of CS in schools, these teachers, knowledgeable in CS concepts and pedagogy, will have a key role, as stated by the representatives of CNE themselves: "The CS teacher education programs (...) have a fundamental role to ensure that abilities and competencies of the BNCC and those described in the present document are effectively developed by students." (our translation) (MEC/CNE, 2019, p.8). On the other hand, in CNE's proposal, the confusion between integrating $\mathrm{CT}$ to the teaching of all contents and teaching CS concepts also appears, as the text states that CS teachers, among other roles, should "collaborate with other teachers to construct effective narratives to promote sense, meaning, comprehension and use of concepts by students. (...) There are, therefore, broad possibilities for collaborative action with other teachers in other subjects (...) in diverse educational spaces." (p.7, our translation).

The short timeline we presented shows political articulation in Brazil towards the introduction of CT and CS in schools. In academia, a lot of research is being undertaken on CT after Wing's paper: a manual search through the proceedings of the Brazilian Symposium on Computers in Education (SBIE), Workshop on Computers at School (WIE), Workshop on Computing Education (WEI), and Workshop on the Teaching of Computational Thinking, Algorithms and Programming (WAlgProg) yields a total of 171 papers with the expression "computational thinking" in their title, from 2006 to $2020^{2}$. But again, much of this research, while focusing on students from primary and secondary education (Souza et al., 2019), seems oblivious to the fact that, in order for these students to learn about CT, someone must be able to teach them systematically and with grounded knowledge. Out of the 171 papers retrieved in the manual search aforementioned, only 14 had also in their title words closely related to teaching or teachers.

Considering that the Ministry of Education determined that all student teachers, regardless of their field of knowledge, must develop a basic comprehension of computational thinking (MEC/CNE, 2019), which is backed up by the expectations expressed in the proposal for the integration of CS in schools (MEC/CNE, 2021), we pose the following question: what is being effectively done to prepare school teachers and undergraduate student teachers to be able to mediate children's computational thinking development at school?

\footnotetext{
2 The complete list of titles can be accessed at: encurtador.com.br/HNQUW
} 
In this paper, we look at the global scenario and discuss how Brazilian teacher education programs, academic research and government are dealing with these new demands of developing $\mathrm{CT}$ and / or teaching CS in schools, and indicate some key aspects that must be considered for decision-making, curricular adaptations in teacher education programs, and national policies.

In section 2, the first part presents how teacher capacity on CT / CS is being developed worldwide and in Brazil, preservice and in-service. In the second part, we review the Brazilian scientific literature to identify what national researchers tell us about teacher education and CT, ending with some implications drawing from international findings. In section 3, we identify crossroads within the scenario presented, and finally in section 4 we sum up what we have learned and point to future research directions and concrete steps to be taken by all parties involved in the effort of effectively developing the CT competency of school children, student teachers, and HEI faculty.

\section{Teacher Education, Computational Thinking and Computer Science}

Changes in curriculum, particularly when they involve the introduction of new subjects, are known to be challenging for teachers (Finger and Houguet, 2009). Educating teachers within the CT frame of mind, whether preservice or in-service, has been a matter of considerable international discussion $(\mathrm{Li}, 2021)$. The introduction of CT/CS concepts at the school level represent changes in teachers' subject knowledge and pedagogical knowledge, i.e., learning the concepts themselves, and learning the proper methods to teach them (Thompson et al., 2013). The International Society for Technology in Education (ISTE) released in 2018 the Computational Thinking Competencies Standards for Educators (ISTE, 2018), stating that teachers should understand $\mathrm{CT}$ as a foundational and cross-curricular skill, and have content knowledge of its core components. This document considerably raises the standards for educators. In a nutshell, according to ISTE (2018), teachers are expected to: (i) integrate CT practices to the instruction of their specific content area (e.g., Mathematics, Biology, History, etc.); and (ii) develop students' ability to apply CT in their environment. In other words, teachers need to master CT knowledge as applied to their particular discipline, as well as master pedagogical knowledge on how to make students develop their own CT: "By integrating computational thinking into the classroom, educators can support students to develop problem-solving and critical-thinking skills, and empower them for success as CS learners and computational thinkers.” (ISTE, 2018, p.1). In line with this expectation, the K-12 ${ }^{3}$ Computer Science Framework (K-12, 2016) - a document backed up by organizations like the Association for Computing Machinery (ACM), Code.org and the Computer Science Teachers Association (CSTA) - states that secondary school students should be able to "identify complex, interdisciplinary, real-world problems that can be solved computationally" (p.77) (and, eventually, be able to solve them, using CT and CS concepts).

The scenario is Brazil is evolving accordingly. As students are expected, as per BNCC (MEC, 2018), to understand, analyze, define, model, solve, compare and automate problems and their solutions systematically, student teachers from all fields of knowledge must develop a basic comprehension of computational thinking and its implications in teaching-learning processes (MEC/CNE, 2019). The main question is: how are these student teachers being prepared to reach such theoretical and practical knowledge on CT?

\footnotetext{
${ }^{3} \mathrm{~K}-12$ is the terminology used in the United States of America to refer to the 12 first years of education, from kindergarten to 12 th grade
} 


\subsection{Building Teacher Capacity in CT/CS}

The lack of qualified teachers to effectively work with CT in schools is known as a significant challenge worldwide (Menekse, 2015). Code.org ${ }^{4}$, a nonprofit dedicated to expanding access to CS in schools and increasing participation by underrepresented groups, supported by partners such as ACM, CSTA, Google, Microsoft and Amazon, published in 2015 nine policies to make CS fundamental to primary education (Code.org, 2015). Three of them relate to teacher capacity, namely: allocate funding for CS teacher training; implement certification pathways for CS teachers; and create programs at higher education institutions to offer CS to preservice teachers. The K-12 CS framework (K-12, 2016), launched in 2016 in the United States of America (USA), presents conceptual guidelines for CS education, to inform the development of standards and curriculum, build capacity for teaching computer science, and implement computer science pathways. Although mostly focused on curriculum, it raises teacher development as a concern, presenting it as "a critical part of the computer science education infrastructure" (p.168).

\subsubsection{Preservice Teacher Education in CT/CS}

According to the K-12 CS framework (K-12, 2016), in the USA there is a lack of preservice teacher preparation programs in CS: most states have no CS teacher preparation programs at HEI whatsoever. In 2014-15, only 51 CS teachers graduated from the 50 states of the country. Creating new teacher education programs and augmenting the quantity of CS teachers has been a national challenge (Heitin, 2016), and secondary schools struggle to find teachers to give CS classes (K12, 2016). According to Code.org (2018), in 2018 only 33 states in the USA offered CS teacher certification. With the lack of certification pathways for CS teachers, many of those currently teaching CS are certified in another subject. This scenario is not exclusive to the USA: globally, few teacher education institutions offer specific programs for CS teachers (Yadav, Stephenson, \& Hong, 2017). According to Yadav et al. (2017), there has been a considerable focus on professional development for in-service teachers, while there is limited work on preparing preservice teachers to integrate $\mathrm{CT}$ into their future practice.

Meanwhile, Brazil is in the vanguard of CS teacher education: an automatic search in the Ministry of Education online portal (e-MEC) retrieved $91 \mathrm{CS}$ teacher education undergraduate programs (Licenciatura em Computação) distributed across the country ${ }^{5}$. According to MEC's curricular guidelines, CS teacher education undergraduate programs have as their main objective preparing teachers who will be able to educate citizens with competencies needed in an increasingly technological world (MEC, 2016). Nevertheless, there is still no official role for graduates from CS teacher education programs in Brazilian public schools, and there seems to be no planned specific national policy to benefit from the capacity of this "sleeping beauty", as put by Lemos (2013). On the other hand, CNE's recent proposal for the introduction of CS concepts in schools reinforce the importance of these programs (MEC/CNE, 2021) and will probably dramatically increase these teachers' recruitment in a few years.

Having said that, it is also important to mention that CT should not be taken for granted when we consider Brazilian CS teacher education programs. An analysis of 40 pedagogical projects of these programs, which were available online, found mentions of CT in 19 projects only (Silva \& Pontual Falcão, 2021). Among those, only 5 had CT as a course or explicitly mentioned in a course syllabus.

If even CS teacher education programs are responding slowly to the rapid changes in school curricula (MEC, 2018) and teachers' expected competencies (MEC/CNE, 2019), how about the other teacher education programs, which are also expected to include CT in their curriculum

\footnotetext{
${ }^{4}$ https://code.org/

${ }^{5}$ Search performed in July 2021 in: http://emec.mec.gov.br
} 
(MEC/CNE, 2019)? In the international research community, Yadav seems to be the most cited of the few authors discussing preservice teacher education and CT. In a paper from 2017, Yadav, Stephenson and Hong argue that preservice CT courses should focus on CT within the context of the teachers' content areas, while computer programming should be optional for those who are interested in specializing in CS (i.e., obtaining a certification for teaching CS). According to the authors, the goal of CT courses for educators should be to prepare teachers "to incorporate CT skills into their discipline and teaching practice so they can guide their students to use CT strategies" (p. 58). The authors also suggest that existing resources and curriculum standards should be used to integrate CT into preservice teacher education in two main ways: (i) redesigning existing educational technology courses in teacher education programs, in order to approach CT; and (ii) using methods courses to develop preservice teachers' applications of CT in the context of their discipline. In section 2.2, we explore how the Brazilian research community is responding to the need of including $\mathrm{CT}$ in preservice teacher education.

\subsubsection{In-service Teacher Education in CT/CS}

Given the lack of teacher preparation programs worldwide, professional development has been used as a way of preparing in-service teachers to meet the new CT-related demands in primary and secondary education $(\mathrm{K}-12,2016)$. There are online courses for teachers to learn about CT, such as Introduction to Computational Thinking for Every Educator (ISTE, 2020), Computational Thinking Integration (LAUNCH CS, 2020); Code.org Professional Learning program ${ }^{6}$; and varied professional development opportunities from the Computer Science Teachers Association (CSTA, 2020). There is also a plethora of self-learning online resources on CT for educators, such as Code.org, Computing at School's CT guide for teachers (Csizmadia et al., 2015); Barefoot CT concepts and approaches (Barefoot, 2018).

For Brazilian school teachers, language will be a barrier for accessing such content. There is a much lesser number of institutions and websites offering resources in Brazilian Portuguese, including: Programaê (PROGRAMAÊ, 2018), Pensamento Computacional Brasil (Brackmann, 2020), and CIEB (2018). Three online courses were made available by MEC in their Virtual Learning Environment (AVA-MEC) ${ }^{7}$, specifically designed to teach school teachers about CT, and show them how they can integrate it in their classes.

We can see that there has been a trend towards encouraging teachers' autonomy and proactivity. The ISTE CT Competencies for Educators (ISTE, 2018) are presented as "a road map to help educators identify strengths and weaknesses, and seek out professional development opportunities to increase their mastery" (p.1). In their online tool for self-evaluation of digital competences, CIEB states that teachers should use the tool because "it makes teachers protagonists of their own development and guides them to meaningful development and transformation in their pedagogical practice" 8 (our translation). On the website of the Computational Thinking Integration course", teachers can "start and end this course at (their) own convenience; there are no due dates."

Adding to that, there is also a trend towards making teachers think that learning about and applying CT is quick and painless, for anyone truly committed. On Launch CS's website, teachers are expected to "be prepared to integrate computational thinking into their K-8 instruction" after

\footnotetext{
${ }^{6}$ https://code.org/educate/professional-learning

7 http://avamec.mec.gov.br/\#/

8 guiaedutec.com.br/educador

${ }^{9}$ https://launchcs.thinkific.com/courses/computational-thinking-integration-BYOD
} 
a 24-hour course. Code.org's opening message on their webpage on professional development for teachers says that "we make it easy, no matter your background"

However, contrary to the tone of these messages, the lack of background in CT, associated with low level of digital literacy (which is the case of many Brazilian school teachers), will cause anxiety for teachers and difficulties in learning, making the support of instructors much needed (K-12, 2016). The great stress on autonomous learning, in this context, might not be the best path.

Another barrier to CT courses for in-service teachers is the fact that most of this target audience is formed of teachers from backgrounds that are not CS, and thus may not be genuinely interested, and do not perceive usefulness nor take pleasure in the topic, lacking motivation to finish the courses. For instance, in Argentina, there are indicators of high dropout rates in such courses, particularly in the case of teachers who do not work with related topics in their practice (i.e. do not work within STEM or programming) (Scasso et al., 2019).

Another aspect is financial. In order to take the Computational Thinking Integration course, teachers are expected to provide their own devices and materials for each activity: this may mean spending your own money to be able to take a course off working hours, on your own, aiming at professional self-development. This seems a bit unfair with teachers, and quite unrealistic within the Brazilian context where teachers are typically overwhelmed with excessive working hours and low salaries.

The guide for teachers on computational thinking by the Computing at School association (Csizmadia et al., 2015) acknowledges the challenge of building teacher capacity in CT in the foreword by the national coordinator, Simon Humphreys: "No-one underestimates that challenge and I have deep respect for the professionalism of the teachers I meet as they take their first steps in meeting this challenge. It is not easy. New vocabulary needs to be learnt, new skills acquired and new ways of teaching adopted." (p.3). According to Yadav et al. (2017), "[...] preparing teachers to embed these [CT] concepts in their teaching or in their specific subject areas can be a daunting task" (p.208).

Simply making digital resources available is not enough to develop teachers' CT knowledge and abilities. According to Barr and Stephenson (2011), no systematic change that implements CT in schools will be accomplished unless educational policies including teacher preparation are established. Yadav et al. (2017) argue that "training in-service teachers is only a temporary solution to the long-term problem of developing a pipeline of future teachers who are prepared to embed computational thinking in their classrooms. The teacher training needs to begin early on in the teacher preparation programs to allow preservice teachers to understand how computational thinking ideas are related to their content areas" (p.217). A recent literature review (Amiel \& Oliveira, 2018) shows that in-service development for teachers has been done mostly through independent initiatives, with no continuing support as the course ends. This is the case of some of the academic projects undertaken in Brazil in the theme of CT and teacher education, as we discuss in the next section.

\subsection{Academic Research in Brazil on Computational Thinking and Teacher Education}

Some years after Wing's seminal article in 2006, research in CT in education boomed in Brazil (Figure 1). A manual search in the proceedings of the four main national forums in technologies for learning and computing education (SBIE, WIE, WEI and WAlgProg ${ }^{11}$ ) shows that the first

\footnotetext{
10 https://studio.code.org/courses?view=teacher

11 WAlgProg's first edition took place in 2015. In 2020, the workshop did not happen due to restrictions imposed by the COVID-19 pandemic.
} 
post-2006 appearance of the term "computational thinking"12 in a paper title was in 2012, in the Workshop on Computing Education (WEI) ${ }^{13}$. In 2019, there were 46 papers featuring "computational thinking" in their title, considering the proceedings of the four conferences, being 23 papers in WIE only. This might be explained by the publication of BNCC including CT in school curricula in 2018. In 2020, the decrease in the number of publications may be due to the COVID-19 pandemic, which forced all educational institutions to adopt an emergencial online format. This affected not only the teaching-learning process itself, but also the workload of teachers and researchers.

Nevertheless, very few of the papers retrieved address teacher professional development, needs and expected abilities related to CT. Out of the 171 papers published with "computational thinking" in their title since 2012 , only 14 seem to focus on the teacher, i.e., mentioned the word 'teacher' or equivalent terms in their title ${ }^{14}: 2$ from SBIE, 5 from WIE, 1 from WEI, and 6 from WAlgProg. However, one of the two SBIE papers, which mentioned teachers in the title as mediators of the activities, actually referred to the researchers themselves. This leaves us with 13 papers discussing teacher-related aspects in the context of CT, since the first appearance of the term in the cited venues, in 2012. Although this was a limited manual search, only based on titles and on the terms "computational thinking" and "computational reasoning", the results give us an overview of research in the field in Brazil.

It is also worth noting that 15 other papers (out of the 171 publications on CT that were retrieved) were literature reviews or mappings, predominantly investigating CT tools, methods, evaluation, school level, concepts and abilities - but none addressing teachers' needs and / or abilities.

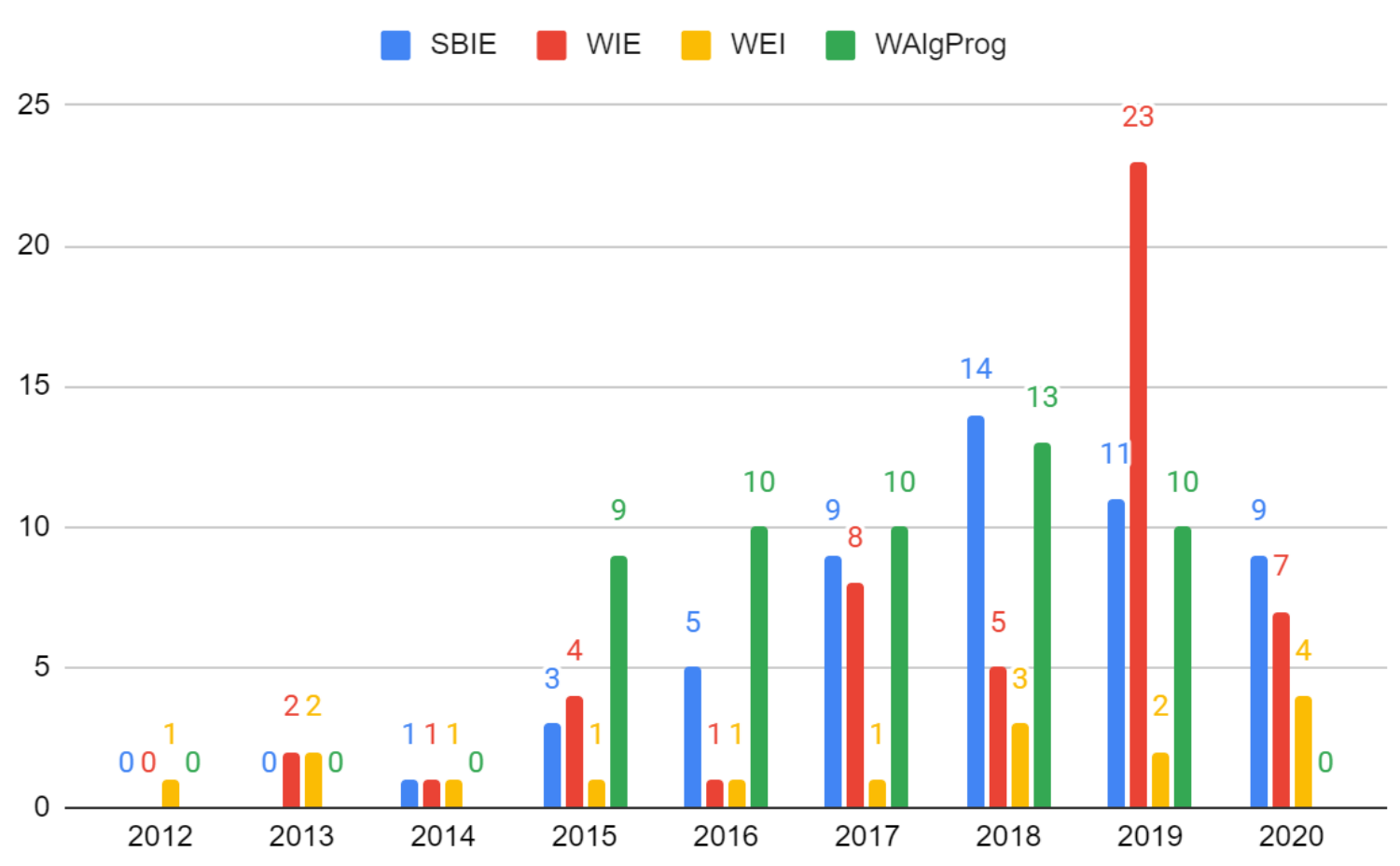

Figure 1: Number of publications with "computational thinking" in their title in SBIE, WIE, WEI and WAlgProg proceedings.

\footnotetext{
12 The search was conducted in Portuguese with the terms: "pensamento computacional" (computational thinking) and "raciocínio computacional" (computational reasoning)

${ }^{13}$ The complete list of titles can be accessed at: https://docs.google.com/spreadsheets/d/1HurnbuIyriX6gSBmik3evhta4iCVvImNfHvsLhULaw/edit?usp=sharing

${ }^{14}$ In Portuguese, the words considered were "professor(e)(s)", "docente(s)" and "licenciado(s)"
} 
França et al. (2014) were the first authors to publish aspects related to teacher education or practice in the context of computational thinking, and this happened quite recently, in 2014. The paper was published in the proceedings of the Workshop on Computing Education (WEI), which, curiously, has not published any other papers on CT and teacher education ever since (Table 1).

Table 1: Publications on computational thinking and teacher education from 2006 to 2020.

\begin{tabular}{|l|c|c|c|}
\hline Educational level & Paper & Year & Venue \\
\hline \multirow{4}{*}{$\begin{array}{l}\text { Research with school } \\
\text { teachers (in-service) }\end{array}$} & Barcelos et al. & 2016 & WAlgProg \\
\cline { 2 - 4 } & Souza et al. & 2016 & WAlgProg \\
\cline { 2 - 4 } & Costa et al. & 2017 & WAlgProg \\
\cline { 2 - 4 } & Leite et al. & 2017 & WAlgProg \\
\cline { 2 - 4 } & Silva et al. & 2017 & WIE \\
\cline { 2 - 4 } & Martinelli et al. & 2018 & WIE \\
\cline { 2 - 4 } & Martinelli and Sakata & 2018 & WIE \\
\hline \multirow{3}{*}{$\begin{array}{l}\text { Research in higher } \\
\text { education (pre-service) }\end{array}$} & Barros et al. & 2018 & SBIE \\
\cline { 2 - 4 } & França et al. & 2014 & WEI \\
\cline { 2 - 4 } & Farias et al. & 2015 & WAlgProg \\
\cline { 2 - 4 } & Barba and Tedesco & 2017 & WIE \\
\hline $\begin{array}{l}\text { Research in higher } \\
\text { education with } \\
\text { instructors }\end{array}$ & Kampff et al. & 2019 & WIE \\
\hline
\end{tabular}

From the 13 papers retrieved in our manual search on $\mathrm{CT}$ and teacher development, 8 present research with teachers in-service (Barcelos, Bortoletto, \& Andrioli, 2016; Barros et al., 2018; Costa et al., 2017; Leite et al., 2017; Martinelli, Zaina \& Sakata, 2018;Martinelli \& Sakata, 2018; Silva, Silva, \& França, 2017; Souza, Rodrigues, \& Andrade, 2019), and 5 developed research in teacher education programs (preservice) (Barbosa, 2019; Farias, Andrade, \& Alencar, 2015; França et al., 2014; França \& Tedesco, 2017; Kampff et al., 2016) (Table 1). This is consonant with the international literature of the field, where the number of studies on preservice teacher education involving CT is much lower than in-service (Li, 2021).

Also worth noting is the fact that among the preservice studies, only one addressed student teachers who were not from CS, but from Mathematics (Barbosa, 2019), and another one worked with HEI instructors (Kampff et al., 2016). The other three were in the context of CS teacher education programs (França et al., 2014; Farias et al., 2015; França \& Tedesco, 2017).

\subsubsection{Research on CT and In-service Teacher Education}

Martinelli, Zaina and Sakata (2018), and Martinelli and Sakata (2018) discuss the participation of school teachers as mediators of $\mathrm{CT}$ activities. Teachers participating in this research firstly were trained in CT, and then had to plan and conduct a CT activity with their students. The analysis showed that teachers were able to develop activities that approached CT as a tool to teach other subjects and/or as a tool and learning goal. Most of the teachers conducted unplugged activities and made use of gamification and learning objects, and very few activities involved a CS topic. The authors point out that much more training is needed to make teachers confident enough to integrate CT fluidly and systematically into their teaching.

This need is also mentioned by Costa et al. (2017) and Leite et al. (2017), who performed interviews with school teachers, and concluded that CT abilities and concepts were little understood and little explored in teaching practices.

Barcelos, Bortoletto and Andrioli (2016), Souza, Rodrigues and Andrade (2016), Silva, Silva and França (2017) and Barros et al. (2018), all conducted CT courses for school teachers, followed by interviews or questionnaires. Overall, teachers found the topic interesting, relatable to their 
practice, and could acquire new specific knowledge. On the other hand, the barrier that the use of technologies still represents for many teachers also appeared in the responses: $79 \%$ of the 40 mathematics teachers interviewed by Barros et al. (2018) declared that in order to use CT concepts in their teaching, they would need the help of an Informatics teacher; and all 13 teachers interviewed by Silva, Silva and França (2017) cited the lack of computer labs as an obstacle to conduct CT activities. Like Martinelli, Zaina and Sajata (2018), Silva, Silva and França (2017) also identified the need for more CT courses for teachers.

Research on in-service teacher education and CT in Brazil is aligned with the international literature, which reports a focus on short-time professional development ( $\mathrm{Li}, 2021)$. It is also consonant with findings abroad reporting teachers' lack of understanding of computing (Sentance \& Csizmadia, 2017) and the need for more professional development opportunities in the area (Menekse, 2015).

\subsubsection{Research on CT and Preservice Teacher Education}

The other five papers developed research in higher education. Only one of them involved instructors from HEI (Kampff et al., 2016). This paper presents the conduction of a short CT workshop for higher education instructors from diverse areas of knowledge, with the aim of disseminating and creating interest in CT beyond CS programs. The authors report that the participants were receptive, recognizing the applicability and importance of CT.

The remaining four papers (Barbosa, 2019; França et al., 2014; Farias et al., 2015; França \& Tedesco, 2017) related to CT in higher education present research performed with student teachers, being three papers with research in the context of CS teacher education programs (Licenciatura em Computação); and one in a mathematics teacher education program (Licenciatura em Matemática).

França et al. (2014) highlight the importance of CS teacher education programs and describe several activities performed by CS student teachers in school internships to promote CT.

Farias, Andrade and Alencar (2015) and França and Tedesco (2017) interviewed student teachers who were near degree completion, about their comprehension of CT and related pedagogical strategies to be used in their future practice as school teachers.

Farias, Andrade and Alencar (2015) found that although most CS student teachers interviewed knew the term CT, they declared not having learned it in the program, but by other means and sources. Additionally, their comprehension of the term was found by the authors not to be adequate.

França and Tedesco (2017) found that the CS student teachers interviewed presented a good understanding of CT. However, it is important to note that the first author of this paper was an instructor in the program and of these students, which probably reflected on their achievement on this specific theme. Besides, this paper was published two years after Farias, Andrade and Alencar's work (2015), and more programs might have added CT to their curriculum during this time, which can also contribute to explain the different results found.

Finally, in the context of a mathematics teacher education program, Barbosa (2019) reflects on her experience as the instructor of the course Informatics and Mathematics Education, as she introduced CT into the syllabus. By the end of the course, the student teachers had to develop a teaching project that articulated CT concepts and the teaching of mathematics, which proved to be a great challenge for them. Barbosa points out that the introduction of $\mathrm{CT}$ in the national curriculum for schools (BNCC) has great implications for teacher education programs that are not being taken into consideration. 
Research on CT and teacher education programs in Brazil is also aligned with the international landscape, where most preservice research investigates student teachers' knowledge on CT, or develops interventions to help them construct such knowledge ( $\mathrm{Li}, 2021)$. Despite the importance of these studies, they are not sustainable as ways to build teachers' capacity. Institutional policies, supported by governments, are the only way to promote large-scale impact.

\subsubsection{Implications}

Overall, academic research on teacher education and CT in Brazil indicates that: (i) when presented to CT, school teachers find it relevant and applicable to their content area, but need more systematic and institutionalized in-service development to be able to integrate it to their practice; (ii) little familiarity with technology can still be a barrier for school teachers to work with CT; (iii) student teachers and HEI instructors have none or little knowledge of CT, even in some CS teacher education programs.

The small proportion of papers on CT that focus on teacher education (around 7,5\% of the 171 papers retrieved) shows that this is still a very incipient discussion in the national landscape - which is quite intriguing, given that teacher education is a necessary condition for CT to be integrated in schools' syllabi.

Moreover, even with a few papers we can notice that, as discussed previously, the trend towards teachers' autonomous learning and professional development in CT is not as simple as some institutions and organizations seem to imply - and, apparently, it is just not happening in the country. The results from the CT workshops conducted by the researchers clearly show that we have a long way to go for actual and effective teacher development in CT in Brazil.

Having said that, we can still find alignments with international findings. Finger and Houguet (2009) present intrinsic and extrinsic challenges teachers face when these changes involve technology education. Intrinsic challenges include: professional knowledge; professional adequacy; professional attitudes and values; teaching approaches; and the extent to which teachers hold ownership of the new curriculum. Professional knowledge, adequacy and attitudes can be noticed in the papers discussed in this section as challenges, such as the lack of familiarity with technologies and lack of CT subject knowledge. The latter is also reported by: Sentance and Csizmadia (2017) from a survey with CS teachers in the United Kingdom; by Yadav et al. (2017) from a survey with preservice teachers in the USA; and by Orvalho (2017) from an experience report about preservice teacher education in Portugal. It comes as a result that teaching approaches indeed are very incipient yet. But perhaps more worrying is the absolute lack of ownership of the intended curriculum. Clearly, both faculty from teacher education programs and school teachers are mostly unaware of the new contents or how to integrate them in their practice, showing that this was not co-constructed. As a consequence, not only faculty and school teachers become familiar with the official policies and the proposed curriculum, will they be able to properly engage in professional development.

Extrinsic challenges proposed by Finger and Houguet (2009) include: lack of resources; practicality of implementation; time management; and methods for student assessment. These are also consonant with the national context. In particular, the lack of resources affects schools since computers were first introduced (Elia, 2021), and decades later we still need programs and policies aiming to properly equip all schools - a level we are still far from reaching. This has obvious direct implications for teacher practice and the practicality of the implementation of a curriculum involving CT and CS concepts - thus the popularity of unplugged approaches in Brazilian schools. 


\section{Crossroads}

When digital technologies started to be introduced in Brazilian schools, more than 30 years ago (Elia, 2021), there was an expectation that the mere delivery of computers to schools would cause a revolution in the teaching-learning process. As we know, this did not happen, and the view on the role of technologies in education has evolved to a broader perspective according to which the integration of technologies and computing to formal learning is a complex process that demands practitioners formally prepared (Zorzo et al., 2017).

However, currently in Brazil, there seems to be contradictions between guidelines regarding integration of CS and / or CT to school curricula, and policies for teacher education and development. While some organizations (such as SBC and CIEB) highlight the importance of CS in society and on how every child should learn to think computationally - and maybe even program computers - much less attention is given to the ones who are expected to make this change happen in schools: the teachers (Barbosa, 2019).

Despite having issued standards for teacher education in 2019 including CT as a necessary knowledge in all fields of knowledge, the Brazilian Ministry of Education (MEC) is clearly concentrating efforts on in-service CT training for school teachers rather than preservice. There are also a few academic researchers who, typically, deliver CT workshops to school teachers, find the topic is promising, and leave (Barcelos, Bortoletto, \& Andrioli, 2016; Barros et al., 2018; Costa et al., 2017; Leite et al., 2017; Martinelli, Zaina, \& Sakata, 2018; Martinelli \& Sakata, 2018; Silva, Silva, \& França, 2017; Souza, Rodrigues, \& Andrade, 2016). We cannot blame them, though. It is not their place and role to institutionalize CT development. At most, they can encourage it and scientifically show its potential.

There are key aspects in in-service CT development to be considered: the extra burden placed on teachers' already very demanding routine; the lack of official role for the CS teachers in schools; and the lack of initiatives and formal links with preservice teacher education.

Public school teachers in Brazil face extenuating working hours and conditions, and can hardly achieve basic expectations. For decades, there have been programs and policies to disseminate the integration of digital technologies in teaching (Elia, 2021), and we have not got there yet. While many teachers still struggle to use tablets, smartphones and robotic kits, they are now facing the new expectation to learn about CT (autonomously, in online courses during extra working hours...) and integrate it to the teaching of their particular content area. This is an extremely complex process (Barbosa, 2019) and not as feasible as presented in the online courses on CT for school teachers in AVA-MEC and other international sources (ISTE, 2020; LAUNCH CS, 2020). For them, CT is totally alien to anything they have studied at university.

Contrary to the current policy of the Brazilian government, most researchers argue that preservice education is more effective than in-service (Cabrera et al., 2018; Vicari, Moreira, \& Menezes, 2018). Reasons include the fact that preservice teachers tend to be more susceptible to new contents; and the facility to systemically integrate CT in teacher preparation programs when compared to in-service ( $\mathrm{Li}, 2021)$. Pre-service education also tends to alleviate teachers' burden and lack of motivation in in-service courses when they are not from the field (Scasso et al., 2019). Nevertheless, at the higher education institutions, faculty (i.e. teacher educators) seem unaware of the demands to develop CT knowledge and abilities of their student teachers.

The curriculum of teacher education programs in Brazil still gives very little attention to educational technologies, and has no content related to CT. Curriculum redesign demands high engagement from faculty at the HEI, who - let us not forget - must themselves learn about CT in the first place (most of them will never have heard about it either), and then make their student teachers think computationally (Yadav, Stephenson, \& Hong, 2017). Yadav et al. (2017) argue 
that "it is time for teacher educators to transform educational technology toward computing education and to structure courses to engage preservice teachers in computational thinking tools and ideas" (p. 218). On the other hand, in interviews with experts in the CT education field, Li (2021) found that faculty members lack motivation and capacity to consider CT integration into teacher education programs.

This seems to be a "chicken and egg" challenge: who will teach the HEI faculty about CT, so that they can teach their student teachers? If we take a top-down approach, we would be first focusing on developing faculty capacity, who will then apply CT in the undergraduate teacher education programs. As they are employed in schools, the novice teachers, who were students in these redesigned programs, would be able to apply CT within their own discipline.

If we go bottom-up and only provide in-service teacher development on CT, novice teachers will keep entering schools with no knowledge on CT, and continuously in need of in-service development - which does not seem reasonable, since we know a priori they will be needing this knowledge.

But how about teaching children Computer Science, as recommended by SBC and CIEB in Brazil, and by ISTE, CSTA and other organizations abroad? Brazil seems to have this thought of for decades now, with the CS teacher education undergraduate programs, which prepare teachers who are able to implement the computing curriculum in schools, including the development of CT.

The SBC standards for CS undergraduate programs (Zorzo et al., 2017) state that graduates from CS teacher education programs have the great responsibility of presenting computing as a science in schools, and, consequently, in society. They should be familiar with the mathematical foundations of CS, but also with themes related to CT, contributing to educating citizens who will promote economic and social development of the country. International organizations also highlight the importance of creating specific paths for the professional development of CS teachers, as stated in the Annual Report on K-12 Computer Science, in the USA (CODE.ORG, CSTA, \& ECEP ALLIANCE, 2020).

So why are the CS teacher education programs, and the novice teachers they deliver to society, not officially designated as CS school teachers in current national policies? Leaving the core CS concepts to actual CS teachers would alleviate the burden from teachers from other disciplines, who could focus on CT - which, as argued previously, is still a lot to cope with.

\section{Closing Key Points: Where Do We Go From Here?}

Integrating a new concept to the curriculum of a country's basic education, that spans across all disciplines, is a complex process which involves several stakeholders: not only students, schoolteachers, and school managers, but also faculty from teacher education programs, student teachers, HEI administration and curricula.

At present in Brazil, when it comes to CT, research efforts, institutional guidelines and national policies have focused on the needs of the next generation of young citizens, i.e., the CTrelated abilities and skills that students who are in schools now will be expected to have in their future professional life, and how they should be developing such abilities and skills during their school years. For this matter, there are many CT resources available for teachers to learn about $\mathrm{CT}$ and materials to be used in lessons, plus official guidelines and curriculum about what to teach when it comes to CT. 
But the fact that we do not yet see changes in teachers' practice in Brazil should serve as an alert that we are facing a complex problem that urges for a broader systemic perspective. In particular, we need to focus on building teacher capacity at all teaching levels and areas.

In a nutshell, this is what we know so far:

1. CT has been introduced in the national standards for schools (BNCC);

2. Consequently, school teachers must learn about CT to know how to integrate it into the teaching of their particular content area;

3. In-service development is being offered to school teachers, but it is crucial (and quite obvious) that preservice CT development also be implemented;

4. In order to implement preservice development, curriculum of teacher education undergraduate programs must include CT (as already timidly but officially stated by MEC);

5. Thus, faculty (instructors) from teacher education programs must learn about CT themselves, applied to each content area, to be able to teach their student teachers;

6. CS teacher education programs must accelerate the inclusion of CT in their curriculum, considering not only the subject knowledge, but also pedagogical knowledge (and ways to implement it in schools).

Figure 2 summarizes the key stakeholders and needs in the present scenario. The situation in schools (bottom board in Figure 2), seems quite fixed, at least in theory: CT is included in the $\mathrm{BNCC}$, and teachers are being given in-service CT development courses. However, at the higher education level (top board in Figure 2), there are important aspects - which are prerequisites for the plans for schools to actually work - that are being mostly ignored so far: the need to include $\mathrm{CT}$ in curriculum of teacher education programs (MEC/CNE, 2019); and the need to give inservice CT development for HEI instructors. Collaboration between Education and CS faculty is one of the envisioned ways (Barr \& Stephenson, 2011; Yadav, Stephenson, \& Hong, 2017; Li, 2021) to achieve these goals, given that integrating CT into the curriculum involves concepts used by computer scientists.

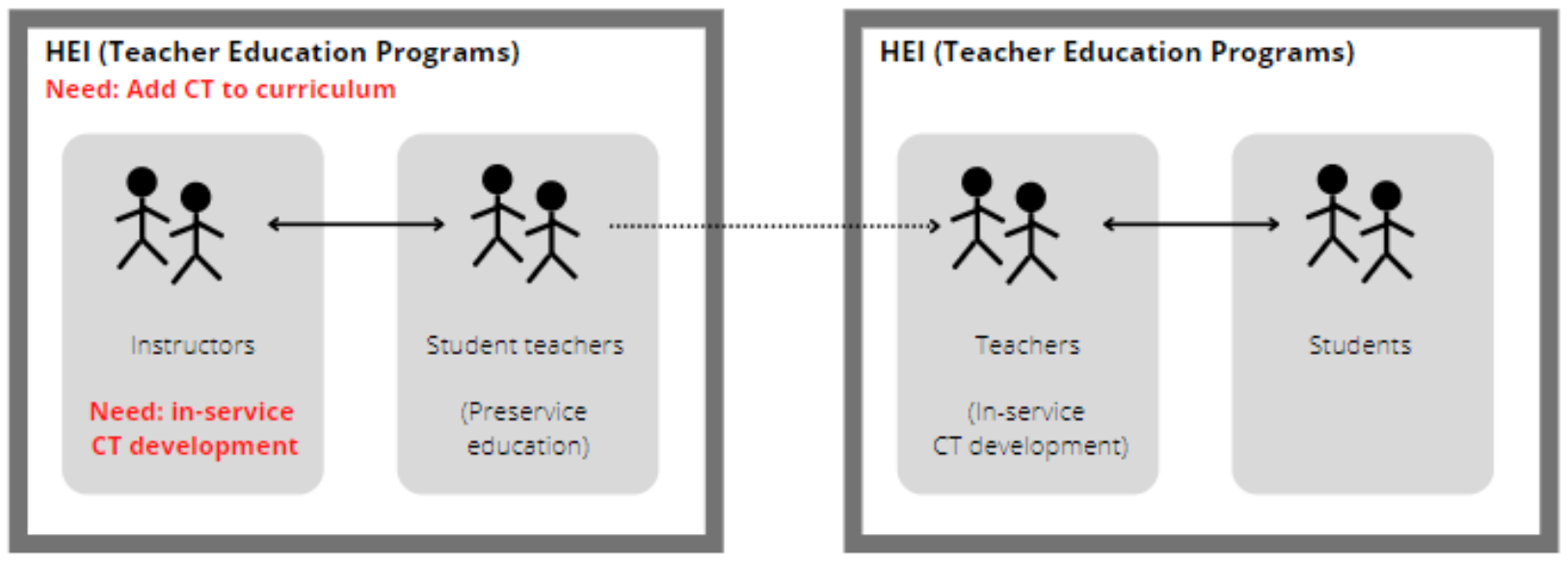

Figure 2: Scenario for computational thinking development in the Brazilian educational system.

As we discussed in this paper, there is a key player in the Brazilian context that has the potential to make a great contribution in this scenario: the CS teacher education undergraduate programs (Licenciatura em Computação). Although the first of these programs was created more than two decades ago, the graduation rate is relatively low (SBC, 2019b). In 2019, 3.038 students entered CS teacher education programs in Brazil, but only 786 graduated in that same year (SBC, 2019b). This is not surprising, given the absence of public policies for the teaching of CS concepts in schools, and the consequent lack of motivation to pursue the teaching career. With the recent advances towards the introduction of CS in Brazilian school curricula, we must not only have 
more graduates, but also increase the number of such programs in the country. In addition, it is also of utmost importance to strengthen programs aimed at developing student teachers' professional practice and identity through immersion in schools (e.g. Programa Institucional de Bolsas de Iniciação a Docência - PIBID; and Residência Pedagógica). These programs help retain students, not only through motivational aspects but also financially speaking, due to the scholarships. CS teachers must receive the same "status" as other school teachers, which so far has not been the case.

Nevertheless, the increasing movement pro-inclusion of CS in schools have given renewed strength to the community of CS teacher education programs (faculty, researchers and students), which culminated in the creation in 2021 of a national network (Rede da Licenciatura em Computação - ReLic) connecting all interested partners and supported by SBC. ReLic reflects a political position, but also has technical and scientific roles in the current scenario towards the introduction of CT/CS in school curricula and teacher education programs. The creation of ReLic results from the articulation of faculty from different CS teacher education programs in Brazil, who shared similar expectations and frustrations within the challenging scenario faced by these programs. However, ReLic is not restricted to these specific programs, aiming to create a collaborative movement involving researchers, managers, teachers, students and alumni, interested in aspects related to teacher education and the inclusion of CS in schools. ReLic is nascent and still being structured, but already had participants from 17 different states of Brazil, within three months of creation, indicating latent desire and need for a space of articulation of dialogues and practices to benefit and boost the teaching of CS in Brazilian schools.

The interdisciplinarity sought by ReLic well reflects the Education-CS collaboration which is intrinsic to the Brazilian CS teacher education programs, whose curriculum is constructed around pedagogical principles, learning theories and CS core concepts. As a matter of fact, interdisciplinarity should be also truly implemented at HEI. Faculty from CS and Education involved in CS teacher education programs have key roles in this process (Barr \& Stephenson, 2011; Li, 2021): they should be applying their expertise to collaborate with specialists from other areas to adjust the curricula of all undergraduate teacher education programs. They should be thinking about options like having a basic CT course in all teacher education courses, or including CT concepts in the educational technologies and methods courses, for example (as suggested by Yadav, Stephenson and Hong (2017)).

Nevertheless, changes in curriculum are rather complex and time consuming. The current national guidelines on teacher education (MEC/CNE, 2019) point to the inclusion of CT and digital phenomena, but this is only the beginning of a long path. Courses related to digital literacy that are currently offered within teacher education programs must have their contents revised in order to favor the conscious and critical use of digital technologies in pedagogical practice. Furthermore, the manner through which the new proposed abilities will be implemented in the curricula must be discussed and planned, perpassing different axes of CS, and enabling student teachers to apply this knowledge in their specific area. For each field of knowledge, this means establishing dialogues not only with experts in CS Education, but also in pedagogical theories, avoiding a technical and pragmatic conception for teacher education. In this context, ReLic is a potential channel to favor such dialogues, co-constructions and practices which effectively promote teacher education in CS concepts, even when not their field of study.

To sum up, we envision three ways in which faculty from CS teacher education programs could collaborate with faculty from other teacher education programs: (i) helping redesign curricula to include CT; (ii) training instructors from other teacher education programs on CT concepts and applications; (iii) acting as instructors of CT courses in every teacher education program. 
As for the graduates from the CS teacher education programs, once employed in schools, they could: (i) teach CT and CS to students; (ii) collaborate with other school teachers to promote interdisciplinarity with CT a cross-cutting theme (as recommended by MEC/CNE (2021)). By working side by side with other school teachers to help them use CT associated with their content area, CS teachers would help build the ever dreamed interdisciplinarity. They could alleviate the burden on teachers from other disciplines, and fulfill their role of contributing for the education of citizens who will promote economic and social development in our increasingly technological world, as stated by the Brazilian Computer Society.

\section{Extended Awarded Article}

This publication is an extended version of an awarded paper at the Brazilian Symposium on Computing Education (EduComp 2021), entitled "Computational Thinking for All: What Does It Mean for Teacher Education in Brazil?”, DOI: 10.5753/educomp.2021.14505.

\section{References}

Amiel, T., \& Oliveira, T. P. (2018). A formação docente em serviço para e sobre tecnologia: uma revisão sistemática. Rede de Inovação para a Educação Brasileira. Retrieved from: http://www.cieb.net.br/evidencias/revisoes/10 [GS Search]

Barbosa, L. (2019). A inserção do Pensamento Computacional na Base Nacional Comum Curricular: reflexões acerca das implicações para a formação inicial dos professores de matemática. In Anais do XXV Workshop de Informática na Escola (pp. 889-898). SBC. DOI: 10.5753/cbie.wie.2019.889 [GS Search]

Barcelos, T., Bortoletto, R., \& Andrioli, M. (2016). Formação online para o desenvolvimento do Pensamento Computacional em professores de Matemática. In Anais dos Workshops do Congresso Brasileiro de Informática na Educação (Vol. 5, No. 1, p. 1228). DOI: 10.5753/cbie.wcbie.2016.1228 [GS Search]

Barefoot. (2018). Computational Thinking Concepts and Approaches. Barefoot online guides. Retrieved from: https://www.barefootcomputing.org/concept-approaches/computationalthinking-concepts-and-approaches [GS Search]

Barr, V., \& Stephenson, C. (2011). Bringing computational thinking to K-12: what is Involved and what is the role of the computer science education community?. ACM Inroads, 2(1), 4854. DOI: $10.1145 / 1929887.1929905$ [GS Search]

Barros, T., Reategui, E., Radaelli, R., \& Teixeira, A. (2018). Análise de Discurso e de Conteúdo de uma Formação em Pensamento Computacional para Professores. In Proceedings of the Brazilian Symposium on Computers in Education (Simpósio Brasileiro de Informática na Educação-SBIE) (Vol. 29, No. 1, p. 1733). DOI: 10.5753/cbie.sbie.2018.1733 [GS Search]

Brackmann, C. P. (2020). Pensamento Computacional Brasil. Retrieved from: http://www.computacional.com.br/

Cabrera, K., Morreale, P., \& Li, J. J. (2018). Computer science + education: an assessment of CS professional development. Journal of Computing Sciences in Colleges, 33(3), 141-147. DOI: 10.5555/3144687.3144719 [GS Search]

CIEB. (2018). Currículo de Referência em Tecnologia e Computação. Centro de Inovação para a Educação Brasileira. Retrieved from: https://curriculo.cieb.net.br/ 
CIEB. (2020). Currículo de Referência - Itinerário Formativo em Tecnologia e Computação. Centro de Inovação para a Educação Brasileira. Retrieved from: https://cieb.net.br/itinerarioensino-medio/

CODE.ORG. (2015). Nine Policy Ideas to Make Computer Science Fundamental to K-12 Education. Retrieved from: http://code.org/files/Making_CS Fundamental.pdf

CODE.ORG. (2018). 2018 State of computer science education: Policy and implementation. Retrieved from: https://code.org/files/2018 state of cs.pdf [GS Search]

CODE.ORG, CSTA, \& ECEP ALLIANCE. (2020). State of Computer Science Education: Illuminating Disparities. Retrieved from: https://advocacy.code.org/stateofcs [GS Search]

Costa, L. D. S., Cavalcante, A., Araujo, A. L. S. O., Andrade, W., \& Guerrero, D. (2017). Um estudo exploratório da aplicação de pensamento computacional baseado nas perspectivas de professores do ensino médio. In Anais dos Workshops do Congresso Brasileiro de Informática na Educação (Vol. 6, No. 1, p. 992). DOI: 10.5753/cbie.wcbie.2017.992 [GS Search]

Csizmadia, A., Curzon, P., Dorling, M., Humphreys, S., Ng, T., Selby, C., \& Woollard, J. (2015). Computational thinking - A guide for teachers. Computing at School. Retrieved from: https://community.computingatschool.org.uk/resources/2324/single [GS Search]

CSTA. (2020). Quality Professional Development Opportunities for K-12 CS teachers. Computer Science Teachers Association. Retrieved from: https://csteachers.org/page/quality-pd

Elia, M. F. (2021). A História da Informática na Educação no Brasil: uma narrativa em construção. In: Santos, E. O.; Sampaio, F. F.; Pimentel, M. (Org.). Informática na Educação: sociedade e políticas. Porto Alegre: Sociedade Brasileira de Computação (Série Informática na Educação CEIE-SBC, v.4). Retrieved from: https://ieducacao.ceiebr.org/historiainformaticaeducacao

Farias, A., Andrade, W., \& Alencar, R. (2015). Pensamento computacional em sala de aula: Desafios, possibilidades e a formação docente. In Anais dos Workshops do Congresso Brasileiro de Informática na Educação (Vol. 4, No. 1, p. 1226). DOI: 10.5753/cbie.wcbie.2015.1226 [GS Search]

Finger, G., \& Houguet, B. (2009). Insights into the intrinsic and extrinsic challenges for implementing technology education: Case studies of Queensland teachers. International Journal of Technology and Design Education, 19(3), 309-334. DOI: 10.1007/s10798-0079044-2 [GS Search]

França, R., Ferreira, V., de Almeida, L., \& do Amaral, H. (2014). A disseminação do pensamento computacional na educação básica: lições aprendidas com experiências de licenciandos em computação. In Anais do XXII Workshop sobre Educação em Computação (pp. 219-228). SBC. ISSN 25956175 [GS Search]

França, R., \& Tedesco, P. (2017). Pensamento computacional sob a perspectiva de licenciandos em computação. In Anais do Workshop de Informática na Escola (Vol. 23, No. 1, pp. 795 804). DOI: $10.5753 / \mathrm{cbie} . w i e .2017 .795$ [GS Search]

Heitin, L. (2016). Physics not offered at 2 in 5 high schools, analysis finds. Education Week, 36(1), 6. [GS Search]

ISTE. (2018). Standards for Educators: Computational Thinking Competencies. International Society for Technology in Education. Retrieved from: http://iste.org/standards 
ISTE. (2020). Introduction to Computational Thinking for Every Educator. International Society for Technology in Education. Retrieved from: https://www.iste.org/learn/isteu/computational-thinking

Kampff, A. J. C., Lopes, T., Alves, I. M., de Souza, V. C., Rigo, S., \& Marson, F. (2016). Pensamento Computacional no Ensino Superior: Relato de uma oficina com professores da Universidade do Vale do Rio dos Sinos. In Anais dos Workshops do Congresso Brasileiro de Informática na Educação (Vol. 5, No. 1, p. 1316). DOI: 10.5753/cbie.wcbie.2016.1316 [GS Search]

K-12 Computer Science Framework. (2016). Led by: Association for Computing Machinery, Code.org, Computer Science Teachers Association, Cyber Innovation Center, and National Math and Science Initiative. Retrieved from: http://www.k12cs.org [GS Search]

LAUNCH CS. (2020). Computational Thinking Integration. LAUNCH Computer Science. Retrieved from: https://launchcs.thinkific.com/courses/computational-thinking-integration

Leite, M., Reinaldo, F., Maschio, E., Marczal, D., \& Oliveira, C. M. (2017). Pensamento Computacional nas Escolas: Limitado pela Tecnologia, Infraestrutura ou Prática Docente?. In Anais dos Workshops do Congresso Brasileiro de Informática na Educação (Vol. 6, No. 1, p. 1002). DOI: 10.5753/cbie.wcbie.2017.1002 [GS Search]

Lemos, A. S. (2013). Entre Patinho Feio e Bela Adormecida: em busca do sentido de uma Licenciatura em Computação. Revista Espaço Acadêmico, 13(148), 10-17. [GS Search]

Li, Q. (2021). Computational thinking and teacher education: An expert interview study. Human Behavior and Emerging Technologies, 3(2), 324-338. DOI: 10.1002/hbe2.224 [GS Search]

Martinelli, S. R., Zaina, L. A. M., \& Sakata, T. C. (2018). O Pensamento Computacional em Atividades de Ensino mediadas pelo Professor do Ensino Fundamental I: Um Estudo de Caso. In VII Congresso Brasileiro de Informática na Educação (CBIE 2018). Anais do XXIV Workshop de Informática na Escola (WIE 2018). DOI: 10.5753/cbie.wie.2018.509 [GS Search]

Martinelli, S., \& Sakata, T. (2018). A disseminação do Pensamento Computacional por docentes do Ensino Fundamental I: Relatos de Experiências e Discussões. In Anais do Workshop de Informática na Escola (XXIV WIE) (Vol. 24, No. 1, pp. 235-244). DOI: 10.5753/cbie.wie.2018.235 [GS Search]

MEC. (2016). Diretrizes Curriculares Nacionais para os Cursos de Graduação em Computação. Resolução CNE/CES no 05 de 16 de novembro de 2016. Retrieved from: http://portal.mec.gov.br/index.php?option=com_docman\&view=download\&alias $=52101$ -

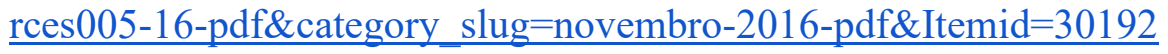

MEC. (2018). Base Nacional Comum Curricular (BNCC). Ministério da Educação. Retrieved from: http://basenacionalcomum.mec.gov.br/

MEC/CNE. (2019). Resolução CNE/CP N 2, de 20 de dezembro de 2019. Define as Diretrizes Curriculares Nacionais para a Formação Inicial de Professores para a Educação Básica e institui a Base Nacional Comum para a Formação Inicial de Professores da Educação Básica (BNC-Formação). Retrieved from: https://bit.ly/39fwsZU

MEC/CNE. (2020). Normas sobre Computação na Educação Básica - Complemento à BNCC. Conselho Nacional de Educação, Ministério da Educação, Brasil. Retrieved from: http:/portal.mec.gov.br/conselho-nacional-de-educacao/audiencias-e-consultas-publicas 
Menekse, M. (2015). Computer science teacher professional development in the United States: a review of studies published between 2004 and 2014. Computer Science Education, 25(4), 325-350. DOI: 10.1080/08993408.2015.1111645 [GS Search]

Orvalho, J. (2017). Computational Thinking for Teacher Education. In Scratch 2017 BDX: Opening, Inspiring, Connecting (p.6). HAL id: https://hal.inria.fr/hal-01555455 [GS Search]

Papert, S.; Solomon, C. (1972). Twenty things to do with a Computer. Educational Technology Magazine. Retrieved from: http://www.stager.org/articles/twentythings.pdf [GS Search]

PROGRAMAÊ. (2018). Um guia para construção do pensamento computacional. Fundação Telefônica Vivo; Fundação Lemann. ISBN 978856019547 3. Retrieved from: http://programae.org.br/educador/

SBC. (2018). Nota técnica da Sociedade Brasileira de Computação sobre a BNCC-EF e a BNCCEM. Retrieved from: https://www.sbc.org.br/institucional-3/cartas-abertas/category/93cartas-abertas

SBC. (2019a). Diretrizes para Ensino de Computação na Educação Básica. Sociedade Brasileira de Computação. Retrieved from: https://www.sbc.org.br/documentos-da-sbc/category/203educacao-basica

SBC. (2019b). Educação Superior em Computação Estatísticas 2019. Retrieved from: https://www.sbc.org.br/documentos-da-sbc/category/133-estatisticas

Scasso, M., Marino, V., Colobini, A., Bortolotto, G. (2019). Evaluación de la Iniciativa Program.AR: Cursos de Didáctica de la Programación y Talleres en Escuelas Secundarias. Fundación Sadosky. Retrieved from: http://www.fundacionsadosky.org.ar/wpcontent/uploads/2019/11/Resumen Informe-evaluaci\%C3\%B3n-de-procesos IniciativaProgram.AR .pdf

Sentance, S., \& Csizmadia, A. (2017). Computing in the curriculum: Challenges and strategies from a teacher's perspective. Education and Information Technologies, 22(2), 469-495. DOI: 10.1007/s10639-016-9482-0 [GS Search]

Silva, I. S. F, \& Pontual Falcão, T. (2021). Uma pesquisa documental sobre o pensamento computacional no ensino superior: análise dos projetos pedagógicos dos cursos de licenciatura em computação no Brasil. Revista Contexto \& Educação, 36(114), 54-71. DOI: 10.21527/2179-1309.2021.114.54-71 [GS Search]

Silva, V., da Silva, L. L., \& França, R. (2017). Pensamento computacional na formação de professores: experiências e desafios encontrados no ensino da computação em escolas públicas. In Anais do Workshop de Informática na Escola (Vol. 23, No. 1, pp. 805-814). DOI: 10.5753/cbie.wie.2017.805 [GS Search]

Souza, F., Leite, R., Brito, C. M., Villela, M., \& Santos, C. Q. (2019). O desenvolvimento do Pensamento Computacional além do ensino em ciências exatas: uma revisão da literatura. In Proceedings of the Brazilian Symposium on Computers in Education (Simpósio Brasileiro de Informática na Educação-SBIE) (Vol. 30, No. 1, p. 528). DOI: 10.5753/cbie.sbie.2019.528 [GS Search]

de Souza, I. M. L., da Silva Rodrigues, R., \& Andrade, W. (2016). Introdução do pensamento computacional na formação docente para ensino de robótica educacional. In Anais dos Workshops do Congresso Brasileiro de Informática na Educação (Vol. 5, No. 1, p. 1265). DOI: $\underline{10.5753 / \text { cbie.wcbie.2016.1265 [GS Search] }}$ 
Thompson, D., Bell, T., Andreae, P., \& Robins, A. (2013). The role of teachers in implementing curriculum changes. In Proceedings of the 44th ACM technical symposium on Computer science education (pp. 245-250). DOI: 10.1145/2445196.2445272 [GS Search]

Vicari, R. M., Moreira, A., Menezes, P. B. (2018). Pensamento Computacional: Revisão Bibliográfica. Projeto UFRGS/MEC Avaliação de Tecnologias Educacionais. Retrieved from: https://lume.ufrgs.br/handle/10183/197566 [GS Search]

Yadav, A., Stephenson, C., \& Hong, H. (2017). Computational Thinking for Teacher Education. Communications of the ACM, 60(4), 55-62. DOI: 10.1145/2994591 [GS Search]

Yadav, A., Gretter, S., Good, J., McLean, T. (2017). Computational Thinking in Teacher Education. In: Rich, P. J., Hodges, C. B. (Eds.), Emerging Research, Practice, and Policy on Computational Thinking. Educational Communications and Technology: Issues and Innovations. Springer International Publishing. DOI: 10.1007/978-3-319-52691-1_13 [GS Search]

Wing, J. (2006). Computational Thinking. Communications of the ACM, 49(3), 33--35. DOI: $\underline{10.1145 / 1118178.1118215 \text { [GS Search] }}$

Zorzo, A. F., Nunes, D., Matos, E. S., Steinmacher, I., Leite, J. C., Araújo, R., Correia, R. C. M., \& Martins, S. (2017). Referenciais de Formação para os Cursos de Graduação em Computação. SBC. ISBN 978--85--7669--424--3. Retrieved from: https://www.sbc.org.br/documentos-da-sbc/category/131-curriculos-de-referencia 